\title{
EFFECTS OF DOMESTIC DEBT ON INTEREST RATES IN NEPAL
}

\author{
Vishnu Prasad Timseena, PhD*
}

\begin{abstract}
Domestic debt has greater implications on macroeconomic stability and growth. Domestic borrowing can lead to crowding out effect, which can lower the economic growth. In this regard, the study of interest rate effect of the domestic borrowing would be useful to the policymakers and other researchers as well. The time series techniques are used to analyze the relationship between the domestic borrowing and interest rate based on annual data for the period 1990-2020. The empirical study reveals that, despite a positive relationship between domestic borrowing and interest rate, the relationship is insignificant and very weak. This implies that increase in domestic borrowings may not result in an increase in interest rates. This is mainly on account of prevailing administered interest rate on long term bond, dominance of fiscal policy in determining the interest rate of auction, lack of investment friendly environment to private sector, high level of liquidity in the economy, information asymmetry problem and many other problems.
\end{abstract}

Key Words: Interest Rates, Domestic Debt

GEL Codes: E43, H63

\section{Introduction}

Government domestic debt has impacts on economy through various channels. One important channel is interest rate channel. Though substantial number of researches done on the effects of domestic borrowing on interest rates, the results are inconclusive. Some researches found significant positive effect of domestic borrowing on interest rates, whereas some others found no effect on interest rates. The study here attempts to review some of these researches over the effects of government domestic debt on interest rates and provide some additional perspectives with regard to Nepal. Generally it is said that expansion in government domestic borrowing causes higher interest rates, may reduce investment and leads to the squeeze of the economy. Therefore, the effect of domestic debt on interest rates has been the matter of focus for the recent policy makers. It would help to explore other researches whether the government domestic borrowings crowd out the private investment in Nepal.

There are currently four types of instruments of domestic borrowings in Nepal. They are treasury bills, development bonds, citizen saving certificates and special bonds. Treasury bills were sold at administered interest rate up to 1988. In the administered system, the amount, interest rates and

\footnotetext{
Associate Professor of Saraswati Multiple Campus (Humanities Faculty: Economics Department), Tribhuvan
} University, Nepal. 
maturity of the treasury bills were determined by the government. The government used to determine a very low level of interest rate (below three month fixed deposit rates). Consequently, a significant amount of treasury bills used to remain unsold in the primary issue and NRB had to own them. But, since 1988, it is being sold at discount rate and the face value is being redeemed to the holder on maturity. Similarly, other interest rates were also administered up to 1990 in Nepal. Still the interest rates of long term bonds, such as citizen saving bonds are administered. Interest rates of development bonds started to determine through auction from 2005 . However, interest rates on deposits and loan of commercial banks were left on market since 1990. Therefore, the study used the data from 1990 to 2020.

This research has been organized as follows. Introduction of the study would be followed by the objectives of the study in the second section. The third section deals with theoretical aspect of domestic debt-interest rate relationship. While the fourth section discusses methodology, data sources and limitations of the study, the fifth section presents the empirical estimation and its interpretation. The last section presents conclusion and recommendations.

\section{Objectives of the study}

- To examine the effect of domestic debt on interest rates in Nepal

\section{Theoretical Underpinnings and Empirical Evidences}

Theory does not provide a clear-cut vision about the effects of domestic debt on interest rates. The impact of domestic debt on domestic interest rate generally depends on a number of key economic parameters. The degree of forward looking behavior of the households and firms in assessing their future liabilities, the degree of openness of the economy and the substitution between private and public goods are the major parameters to determine whether the fiscal policy variable (domestic debt) is a key determinant of interest rates or not.

\section{a) Ricardian Equivalence and standard Text book model (Forward looking behavior of the house holds and firm)}

There are two opposite views to analyze the impact of domestic debt on interest rates. The first is the standard text book model, which predicts that increase in public spending (supported by high debt) boosts the aggregate demand shifting the IS curve to the right and thereby raising short term interest rates. However, Ricardian Equivalence theorem predicts no role of fiscal policy variable on interest rates. Because of the forward-looking behavior of the consumer, they fully anticipate the future tax burden created with the shift from tax to debt financing. In such a case a tax cut does not affect the given interest rates and the public spending remains unchanged. In other words, a debt financed tax cut will leave domestic saving unchanged and hence have no effect on interest rates. In the literature, it is called Ricardian Equivalence Theorem.

Fiscal policy matters in the determination of interest rates if the conditions for Ricardian equivalence are not met, namely if agents are liquidity constrained, have limited horizons, or taxes are distortionary (Faini 2005). 


\section{b) The degree of substitutability between private and public goods:}

The degree of substitutability between private and public goods also has a great implication of the public spending by borrowings rather than tax on interest rate. Interest rates would not change, if the private and publicly provided goods were perfectly substitutes. Because, if the government expenditure increases by borrowing, (i.e. government consumption increases) people starts to save equally to bear the future tax burden i.e. private consumption decreases. So the interest rate remains unchanged. But, if public spending is less than a perfect substitutes of private goods, higher government expenditure would not be fully offset by the increase in private saving, as forward looking consumers anticipate a future expansion in their tax burden on the one hand and also try to smooth consumption over time. As a result, consumption falls but by less than the increase in public spending and the aggregate saving declines, giving interest rate to rise. In general, therefore public spending should have an impact on the level of interest rates, unless private and publicly provided goods are perfect substitutes.

\section{c) The degree of openness of the economy:}

The degree of openness of the economy also determines the effect of fiscal variable (domestic borrowing) in to interest rates. In closed economy, domestic borrowings may have great impact on the interest rates. However, in a small open economy, interest rates are determined by international capital flows. Fiscal policy, therefore, is totally ineffective in influencing the level of interest rates, with any change in domestic saving being offset by international capital flows. If the interest rate is higher in the country, than the world interest rate then, foreign capital enters in the hope of earning more returns and interest rates start to decline until the equilibrium does not restore. However, many studies found that not only international capital flows but also domestic borrowings have some implications on domestic interest rates.

These three economic parameters are the extreme hypotheses, which are unlikely to be met fully in the real world. No, people are fully forward looking and they may not have full mathematical knowledge of future tax burden calculation to compare with the present domestic borrowings. Therefore Ricardian equivalence is not likely to occur in the real world. Similarly private and publicly provided goods could not be the best substitutes of each other. Third, even in the open economy, domestic borrowing has certain implication on domestic interest rates. Therefore, it can be said that domestic borrowings i.e. fiscal policy matters to affect the domestic interest rates; only the degree of impact may be different.

\section{Crowding out effect}

Muhleisen and Towe, (2004) reported that the key fiscal variable in the determination of US and global interest rates is (net) debt. The long run impact of fiscal policy on interest rates can be determined also in the assumption that an increase in budget deficit will lead to a rise in the stock of debt, which could crowd out the stock of productive capital. In turn, reduction in capital stock will, for a given level of employment, be associated with an increase in the marginal productivity of capital and, in equilibrium, of the real interest rates as well (Faini, 2005). Therefore, debt matters in determining the interest rates. 
Some other researchers found no significant relationship between the domestic debt and interest rates. Barro and Sala-I Martin (1994) did not find any significant relationship between the debt and world interest rates. Hoelsher (1983) found that federal borrowing is a relatively unimportant determinant of short-term rates. The degree of increase in interest rate depends upon the slope of LM curve. If the LM curve is horizontal, there is no change in interest rates associated with the change in government spending thus no investment spending is cut off. (Dornbursh, Bodman, Startz, Crosby, Fisher, 2002). So in this situation, there is no effect of increased government spending (increased borrowings) on interest rates. This is liquidity trap position. The fiscal policy has full multiplier effect on the equilibrium level of income in this institution.

But if the LM curve is vertical, an increase in government spending has no effect on income level rather it increases only the interest rate. The increase in interest rate reduces the private investment-spending equal to the increase in government spending. This is full crowding out effect of government borrowings.

In third case, LM curve is neither horizontal, nor vertical. Rather it is upward sloping from left to right. In this situation, increase in government spending (borrowings) increases the interest rates as well as it increases the income. Crowding out is therefore a matter of degree (Ibid, 2002). The increase in aggregate demand (through increased government spending) raises income and there by increased the level of saving. Increase in saving ultimately is helpful to finance a larger budget deficit without completely displacing private spending.

Now it is a turn to excavate the impact of domestic borrowings on interest rates in Nepal. To analyze this relationship precisely, the following empirical methodology is applied.

\section{Data Sources and Limitations}

The data on domestic borrowings and interest rates are obtained from Quarterly Economic Bulletin of the NRB. Quarterly data are used for the study. The sample size of the study is from 1990 to 2020. Difficulty in the availability of data of market interest rates before 1990 is the main limitation of the study. Only the selection of one year saving deposit rates and 91 day treasury bills out of the various types of interest rates has also been another limitation of the study.

As of mid-July, 2020, the total outstanding domestic debt of the government stood at Rs.613212.0 million,16.3 percent of the Gross Domestic Product. In 1990, total outstanding domestic debt was of only Rs 14.7 million. As of mid July, 2020, 91 day TB Rate stood at 1.3 percent, where as in 1990, it was 6.2 percent. In 2020, saving interest rate stood at 6 percent, where as it was 11.5 percent in 1990. 


\section{Chart 1: Domestic Debt, 91 Day TB Rate and 1 Year Saving Interest Rate}



\section{Methodology}

As economic theory is not conclusive in determining whether government domestic debt raises interest rates, and if it does, by how much, then this issue must ultimately be addressed by empirical analysis. The study has applied time series regression approach for the empirical measurement of the relationship between the domestic debt and interest rates.

Two types of interest rates are used in this regard. The first is the 91 days treasury bills rates and the other is the one-year saving interest rate. The regression equation for analyzing the relationship between 91 days TBR and domestic borrowings is as follows:

$\mathrm{dtbr}=\mathrm{a}+\mathrm{bdlnodd}+\mathrm{u}$

Where,

tbr $=91$ days treasury bill rates

odd $=$ outstanding domestic debt

$\mathrm{a}=$ intercept

$b=$ co-efficient

$\mathrm{u}_{\mathrm{t}}=$ error term 
Similarly, the regression equation for analyzing the relationship between one year saving deposit rate and domestic borrowing is:

dasr $=\mathrm{a}+\mathrm{bdlnodd}+\mathrm{u}$

where,

$$
\begin{aligned}
& \text { asr= average one year saving deposit rate } \\
& \text { odd = outstanding domestic debt } \\
& a=\text { intercept } \\
& b=\text { co-efficient } \\
& u_{t}=\text { error term }
\end{aligned}
$$

The result of the empirical analysis is presented in the following table.

\section{Implication of Domestic Borrowing on Interest Rate in Nepal Sample Period (1990 - 2020)}

\begin{tabular}{|c|c|c|c|c|c|c|c|c|}
\hline $\begin{array}{c}\text { Dependent } \\
\text { Variable }\end{array}$ & $\begin{array}{c}\text { Independent } \\
\text { Variable }\end{array}$ & $\begin{array}{c}\text { Equation } \\
\text { Applied }\end{array}$ & $\mathrm{a}$ & $\mathrm{b}$ & $\mathrm{T}$ of b & $\begin{array}{c}\text { Adj } \\
\mathrm{R}^{2}\end{array}$ & $\mathrm{DW}$ & $\begin{array}{c}\mathrm{F}- \\
\text { Statistics }\end{array}$ \\
\hline $\begin{array}{c}\text { 91 days TBs } \\
\text { Rate }\end{array}$ & $\begin{array}{c}\text { Domestic } \\
\text { Debt }\end{array}$ & $\begin{array}{c}\text { dtbr c } \\
\text { dlnodd }\end{array}$ & -0.18 & 0.80 & 0.24 & -0.01 & 1.95 & 0.06 \\
$\begin{array}{c}\text { 1 year } \\
\text { Saving } \\
\text { Deposit Rate }\end{array}$ & $\begin{array}{c}\text { Domestic } \\
\text { Debt }\end{array}$ & $\begin{array}{c}\text { dasr c } \\
\text { dlnodd }\end{array}$ & -0.14 & 0.72 & -0.01 & 1.84 & 0.44 \\
\hline
\end{tabular}

\section{Analysis of the Results}

The empirical finding is that 10 percent increase in the growth of domestic borrowing may result to a 8 percent increase in the 91-day TBs rate. In the case of one year saving deposit rate, 10 percent increase in the growth of domestic borrowing may result to a 7.2 percent increase in average one year saving deposit rate. This supports the theoretical positive relationship between the domestic borrowing and the interest rate. However, this relationship does not seem significant. Therefore in Nepal, though there is a positive relationship between the domestic borrowing and interest rate, this relationship is very weak. This is mainly on account of prevailing administered interest rate on long term bond, dominance of fiscal policy in determining the interest rate of auction, lack of investment friendly environment to private sector (so that, crowd out effect and interest rate effect would not be effective), high level of liquidity in the economy, information asymmetry problem and many other problems. 


\section{Conclusion and Recommendations}

Domestic borrowing is one of the major sources of deficit financing in the developing country like Nepal. As the growth, structure and ownership pattern of domestic debt has great implication for macroeconomic growth and stability, carrying out this type of research on such matter would be very useful for the policy makers especially in establishing co-ordination between fiscal and monetary policy. Domestic borrowing is typically is a fiscal phenomena, but affects monetary policy through interest rate channel. As, the time series least square regression approach does not find strong relationship between interest rates and domestic borrowings in Nepal due to the above mentioned reasons, some major recommendations in this regard may be as follows:

- As the fiscal policy seems effective in determining the interest rates of the bonds in primary as well as secondary transactions of the bonds in the form of imposing cut-off rates when interest rate rise, this practice should be minimized to establish and analyze the strong and positive relationships between the domestic borrowings and interest rates.

- The role of fiscal policy and monetary policy in the domestic debt management should be defined clearly and public debt management function should be shifted outside Nepal Rastra Bank. The market must be allowed to function freely if the market would not clear, the NRB should not finance the residual especially in the case of Treasury Bills.

- $\quad$ Market based bonds market should be developed. Domestic borrowings should be taken not only as instrument of meeting government budgetary deficit but also the instrument of monetary management to affect the interest rate.

- $\quad$ The policy tensions arising from the contradictory objectives of monetary management and fiscal management should be minimized.

- $\quad$ Administered method of pricing long term debt should be converted into auction i.e. market based price determination.

- Information asymmetry problem should be minimized to some of the extent by enhancing the transparency in domestic debt management.

- Investment-friendly environment should be strengthened in the country by spending the amount of domestic borrowing in infrastructure development, so that private sector would be sensitive to change in interest rate.

- $\quad$ Secondary market of the government bonds should be developed.

- The proper compliance of the issue calendar for mobilizing domestic debt should be ensured.

- $\quad$ There should be predictability in the behavior of the government while mobilizing debt. Budgeted domestic borrowings should not be taken as authorization rather it should be taken as commitment. 


\section{References:}

Barro, Robert J and Xavier Sala-I-Martin, 1990,"World Real Interest Rates" National Bureau of Economic Research, Working Paper 3317, April

Barth, James R., George Iden, Frank S. Russek, and Mark Wohar, "Do Federal Deficits Really Matter?" Contemporary Policy Issues Vol.3, no. 1 (Fall), pp.79-95

Baxter, Marianne, and Robert G. King, 1993, "Fiscal Policy in General Equilibrium," American Economic Review Vol.83, no. 3(June), pp. 315-334.

Bohn, Henning, 1998, "The Behavior of U.S. Public Debt and Deficits," Quarterly Journal of Economics Vol. 113, no. 3 (August), pp.949-963.

Cebula,Richard J., and James V. Koch, 1994, "Federal Budget Deficits, Interest Rates, and International Capital Flows: A Further Note," Quarterly Review of Economics and Finance Vol. 34, no. 1 (Spring), pp. 117-120.

Dornbusch Rudiger, Phillip Bodman, Mark Crosby, Stanley Fisher, Rechard Startz, 2002 "Macroeconomics", McGraw Hill Australia.

Engen Eric M., and R. Glenn Hubbard, 2004, "Federal Government Debt and Interest Rates" AEI Working Paper no. 105, June 2.

Faini, Ricardo, 2005 " Fiscal Policy and Interest Rates in Europe", paper prepared for the 41st Panel meeting of Economic Policy in Luxembourg, March.

Faini, Ricardo, 2005 " Fiscal Policy and Interest Rates in Europe", paper prepared for the 41st Panel meeting of Economic Policy in Luxembourg, March.

Holescher, G.P., 1983, " Federal Borrowings and Short-term Interest Rates", Southern Economic Journal, 50, October.

International Monetary Fund, "Government Finance Statistics Yearbook," 2006 and 2007, International Monetary Fund.

Kitchen, John, 2002, "A Note on Interest Rates and Structural Budget Deficits," Mimeograph, October.

Miller, Stephen M., and Frank S. Russek, 1996, "Do Federal Deficits Affect Interest Rates? Evidence from Three Econometric Methods, " Journal of Macroeconomics vol. 18, no.3 (Summer), pp. 403-428.

Muehleisen M., and C. Tower (2004), "U.S. Fiscal Policies and Priorities for Long run Sustainability", IMF occasional paper no 227 